\title{
Feminist Challenge to the Mainstream IR
}

\author{
Gülşen Aydın \\ Assistant Professor, Atatürk University, Department of International Relations,
}

\section{Abstract}

This study deals with the Feminist challenge to the Mainstream International Relations Discipline (IR) - rationalist theories, especially Realism - and the mainstream's responses to this challenge. It addresses the issue in five steps. Firstly, it sheds light on how Feminism is related to International Relations. Secondly, it examines how Feminist IR theorists criticize the Mainstream IR due to its state-centric approach and argue that being obsessed with anarchic international system prevented analysis of social relations, including gender relations. Thirdly, the study addresses how Feminism exposes the gender biases in central terms such as power, autonomy, rationality, security, and state. Fourthly, it examines how Feminist writing on IR challenges the dichotomies of the Mainstream IR. Fifthly, the study examines how the Mainstream has responded to that challenge. The conclusion argues that although Feminist challenge to mainstream IR cannot be deemed successful in reconstructing IR, Feminism still enriches our understanding of global politics.

Keywords: International Relations (IR), Feminism, Realism, state, gender, power.

\section{Introduction}

Feminist approaches, which are at odds with exclusive focus of mainstream International Relations (IR) theory on men, state and war, have proliferated in the Post-Cold War era. ${ }^{1}$ Feminism introduced gender as an appropriate category and theoretical tool for analyzing global power relations and construct alternative world orders.

Until recently, IR focused on the origins of war and conflict, the development of diplomacy and international law and worldwide expansion of trade and commerce and disregarded people. Feminism, together with other perspectives, including Post-Modernism, Constructivism and Critical Theory, aimed at making IR to focus on people. Moreover Feminists vie for replacing the narrow focus of International Relations with a comprehensive and egalitarian framework.

Feminism, together with the new approaches mentioned above, contested the power of the mainstream. Feminism challenged the ontological and epistemological foundations of IR and tried to expose the gender biases in the central terms such as power, autonomy, rationality, security and state. In this paper, I will be dealing with feminist challenge to mainstream's main assumptions and approaches. Besides I will also examine how feminist IR scholars challenge mainstream's understanding of critical concepts I mentioned above. In order to a comprehensive analysis of feminists-mainstream engagements, will also examine the mainstream responses to the challenges posed by some feminist IR scholars such as Ann Tickner. But before doing these, I will try to answer the question are the feminists really doing IR or how the feminists are related to IR?

\section{How Is Feminism Related to IR?}

This section addresses the feminist aims in relation to knowledge in IR in an attempt to expose how is Feminism is related to $I R$.

There is no single Feminist IR Theory but be it Marxist, Liberal or Post-Structuralist, feminists aim to realize one of the three feminist projects in IR identified by V. Spike Peterson (Peterson 2004). The first feminist project aims to show that women's roles and perspectives are excluded from IR besides shedding light on the extent and effects of masculine bias in IR. In this regard, feminists indicate that most knowledge has been formed by men and is about men (Tickner \& Sjoberg 2013, 207). Classical Realism builds its assumption on human nature but human nature under discussion in the works of Thucydides, Machiavelli and Hobbes is the nature of man (Shepherd 2010,6). Ann

\footnotetext{
${ }^{1}$ By the mainstream IR, I mean the theories rely on empiricism and rational actor model in general and Realism in particular.
} 
Tickner is a key feminist writer in this regard who illustrates Realist focus on men and exclusion of women successfully. Conventional theories of IR focus on nation-states to explain world politics, in this kind of analyses individuals came under examination only in relation to these collective identities not for their own sake (Shepherd 2010, 6).

In the first project, which could be regarded as the most successful of Feminist projects in IR, feminists shed light on the omission of actual woman and their activities from IR and demonstrate what change their inclusion wo uld create. Feminist identify various roles that that women perform in international relations, many of which had been seldom recognized by IR prior to the introduction of feminist approaches (Wibben 2004, 105). For example, in Bananas, Beaches and Bases, Cynthia Enloe draw attention to various ways in which women are present in international relations. She argues that the mainstream hides the work carried out by women, as diplomat wives, as sex workers outside military bases, or as poster girls for Chiquita bananas (Enloe 2014). In Nimo's War, Emma's Life: Making Feminist Sense of the War in Iraq, Enloe this time offers an examination of the Iraq War through the perspectives of eight woman, four American and four Iraqi (Enloe 2010).

Feminists argue that IR scholars continue to theorize global politics in a way that make women invisible. As a result they assure that their research agendas remained the same. Feminist charge mainstream IR of exclusively focusing on conflict, anarchy, competition and fear. For the feminists, in this way reproduction of state-system is made possible. Moreover, the analysis of structural violence (poverty, unfair gender relations, socio-political inequality and environmental injustice) is obstructed (True 1996, 239).

Rebecca Grant and Kathleen Newland in their introduction to their book Gender and International Relations discuss that women are excluded international relations theory not because they are, with few exceptions, excluded from the influential circles of decision-making. They argue that women are excluded because IR discipline is based on a gendered division of responsibilities and rights. It assigns reproductive work in private sphere to women, and the duties and decision-making of citizenship, including serving state as soldiers and conducting international politics, to men. They also accuse the IR of extremely focusing on conflict and competition as well as being obsessed with a concept of national security rest on power (Grant and Newland 1991, 1-7). Frank Halliday makes a similar argument in his article "Hidden From International Relations: Women and the International Arena". He posits that since the subject matter of international relations is traditionally defined as "high politics", which concentrates on the issues of state policy and security, gender issues have a quite limited place in the field (Halliday 1994).

The second project of feminist writers in IR is associated with correcting the male bias in mainstream IR by adding woman and their experiences to the existing framework. Feminists argue that mainstream focuses on what man does: working and decision-making in the public sphere. But the background of the narrative cannot be seen. When we add women's lives that background, they will be visible. The invisibility of women in the state of nature is a point in the case (Peterson 2004).

The third project of feminists in IR is to reconstruct the discipline. Feminist IR scholars aim to bring about a rethinking of foundational categories that are biased towards males. Feminists defend that rather than taking some foundational constructs (such as power, rationality security, violence) and dichotomies (war-peace, international-domestic, anarchy-order) for granted, IR should problematize them. It is in this project feminist theories are uniquely transformative, they do not simply 'add to' but subvert and rewrite IR theory (Peterson 2004).

\section{Feminist Challenge To Main Approaches And Assumptions Of Mainstream IR}

Feminist IR theorists criticize the IR field for its state centric approach and argue that a world of states situated in an anarchical international system leaves no room for analyses of social relations, including gender relations. Together with the other critics of Realism, Feminists argue that due to its state-centric bias, realism devalues and often misses other forms of political organization (such as local and transnational non-governmental organizations). Moreover, feminists argue that due to its emphasis on inevitability of the clash of armed states, Realism almost entirely disregards the possibility of politics as a complex form of resolving conflicts among individuals and groups (Runyan 1991, 71).

A feminist perspective also believes that national interest is multidimensional. Therefore, it cannot be defined exclusively in relation to power. In the present-day world, the national interest demands cooperative rather than 
zero-sum solutions to a range of interdependent global problems, which include nuclear war, economic wealth and environmental degradation (Tickner 1992, 37).

Feminists defend that as a result of patriarchal construction of woman by Realism, she has no place in the high politics of anarchical interstate relations. Feminists argue that in the Realist conceptualization, woman is a domesticated figure whose sensibilities are at odds with the harsh realities of the public world of men and states (Runyan 1991, 69). Moreover, due being emotional, women are regarded by the irrational contrary to rational man. In this way, woman is constructed as an "other" and an outsider in international politics. This construction gives rise to the need to domesticate and tame woman- to bring her under control because she can never aspire to having reason herself (Runyan 1991, 69). At this point feminist writers argue that under the patriarchal paradigm of Realism, "woman" -the other, the outsider, the madness is created and then construed as the enemy to be controlled and brought under man/ state's control at any cost. As a result, from the perspective of feminism, realism attempts to contain and repress difference (Runyan 1991, 70). Realism and Neo-Realism claim to explain the world as it is. However, they are responsible for making the world as it is, for the reproduction of global hierarchies of gender and identities such as race, class and ethnicity (True 1996, 247).

Feminists do not agree with claims of Realists like Morgenthau that it is possible to develop a rational theory of international politics based on objective laws that have their roots in human nature. Feminists in general are skeptical about the possibility of finding a universal and objective foundation for knowledge contrary to Morgenthau (Tickner $1988,30)$. Feminist scholars adopted the notion of 'feminist lenses' or 'gender lenses' implying that there are other ways of 'seeing', 'knowing' and 'being' in the world which could give rise to different perspectives (Steans 2003, 435).

\section{Criticisms Towards The Realist Emphasis On Men As Citizens And Political Actors}

Feminists argue that one of the major sources of gender bias in international relations theory is the emphasis on males as citizens and political actors, as seen in several classical concepts of political theory. By adopting the examples included in the classical political theory without considering the gender bias in them, IR theory has duplicated the pattern of bias (Grant 1991, 9).

Feminists challenge the Realists' and Liberals' depiction of man as autonomous. Some feminists suggest an alternative model of the individual as connected, interdependent and interrelated (True 1996, 250). For example, Ann Tickner argues that feminist perspective could transform IR by offering richer and alternative models. She argues that such models, would conceptualize individuals and states as both autonomous and connected, and as having multiple identities and relations (Tickner 1991, 204-206). To say it another way, feminist alternatives do not favor universal Abstractions. Instead they opt for a more historical and cultural contextualization in order to understand the complexity of human agency adequately.

Turning to another side of the issue, Feminists such as Ann Tickner argue that gender is about a set of relational features that we link with masculinity and femininity. The attributes such as power, autonomy and rationality are generally seen as masculine. Other features such as weakness, dependency, emotion and passivity are related with women. As obvious, the characteristics that one should show to be successful in public sphere and the characteristics that we desire to have are related with man. The alternative ways of acting that rely on more cooperative strategies rather than use of power are both delegitimized and associated with femininity (Tickner 2004, 53-54).

\section{Feminist Challenge to The Dichotomies Of The Mainstream IR: Public versus Private, Anarchy versus Order and Domestic versus International}

Feminists argue that dichotomies produced by Realism are patriarchal in character. They exist because these divisions in the world have come true through the constant reproduction of them in narrative and practice.

In Public Man, Private Woman Jean Bethke Elshtain examines what she terms "the public/private prism" to shed light on the meaning of political sphere. Elshtain suggests that we should not only ask the question "what is politics for" but also "what is politics defense against?". She argues that politics is envisaged as a defense against the pull of private, which Elshtain links with female, characterized as unclear, sexual, bodily, and hence omitted from political speech. Men fear the sexual and reproductive power of women. As Elshtain argues because of shame, bodily 
functions are seen as private. Since women are linked with bodily functions, they are considered in the framework of private realm (Elshtain 1981).

Elshtain traces the public/private dichotomy to the Greeks with their basic differentiation between polis and the oikos (household). With the arrival of Liberalism, the dichotomy established by the Greeks is reproduced. Scientism, rationality and instrumentalism came to pervade the public sphere. For Locke, for example, it is rationalism that separates public minds from private desires (Elshtain 1981, 50).

So, Elshtain tries to show that public/private dichotomy is a gendered dichotomy. Whereas man is associated with the public, woman is associated with the private. The separation of the public and private spheres has brought about the legitimation of what are seen as the 'rational' activities such as politics, economics and justice) of the public sphere while belittling the natural activities (such as household management, taking care of children). Since the politics exist in public and woman is identified with the private, the roles that women play in international politics and their experiences are excluded from the field of international politics.

Having examined public/private dichotomy, I want to turn my attention to the issue of anarchy/order dichotomy together with domestic/international.

The fact that internal conflicts are rife within the states and that states sometimes threaten their own populations have weakened the Realist assumptions about the anarchy/order distinction. Feminists question the argument that man fight in the wars to protect women and children. They draw attention to the fact that 80-90 percent of causalities due to the conflict since the World War II have been civilians, the majority of whom have been women and children. Moreover, feminists argue that in the militarized societies women are particularly susceptible to rape and that evidence show that there is higher domestic violence in military families (Ann Tickner 1991). Moreover, the Feminist writers such as Roberts argued that due to gender-blindness Realists made domestic violence against women invisible and as a result Realists came up with made misguiding assumptions about the 'order' within societies, which is often contrasted to the violence between nations and anarchy in the international system (Roberts 1983, 11-14).

\section{Feminist Challenge To Mainstream IR's Key Concepts: Power, Autonomy, Security, Rationality And State}

Feminists assert that women have not been studied in IR because the conceptual framework of the entire field is gendered. They argue that mainstream IR's key concepts are not neutral but derived from a social and political context in which patriarchy is dominant. Feminists argue, for instance, notions of power, security, rationality and state are inseparable from patriarchal division of public and private. They are identified with men's rather than women's experiences and forms of knowledge. Thus, for Feminists, IR is not only gender-biased, but also based on the exclusion of women and feminine attributes (True 1996, 247).

Feminist IR scholars have analyzed the gender bias in each concept examined below and exposed how this gender bias limits our ability to explain and understand the multiple realities of world politics.

\subsection{Power And Autonomy}

Feminist argue that due to the dominance of Realist accounts, power in IR theory is almost exclusively understood as 'power-over': the power to force or influence people to do something that they would not otherwise do. A power of individual rests on his or her autonomy from the power of others. In this view, power cannot be shared. Moreover it cannot be increased by cooperating with others in the context of interdependent or common interest. In the context of an anarchical state system, which is interpreted as hostile and self-help, states act rationally perceive their national interest as their maximization of power-over other states (True 1996, 254).

In their criticism to the mainstream, feminists such as Ann Tickner argue that Realist understanding of power is andocentric (Tickner 1988, 434-435). As the argument goes, this kind of definition of security is shaped by the experiences of patriarchal societies where men's citizenship and personal authority rests on their position as the head-of-household. This concept of power also rests on autonomy and this makes human relationship and affective connections unseen. Many feminists argue that interdependence is as much a human characteristics as autonomy but whereas autonomy is associated with masculinity, femininity is associated with interdependence. It has been argued that since the rise of the modern state system in seventeenth century, autonomy and separation, which is associated with the meaning of sovereignty, shaped our understanding of national interest (Tickner 1992, 64). Betty 
Reardon argues that as a result of this association of autonomy with national interest tends we can't realize the realities of interdependence in the world (Reardon 1985, 64).

Feminist theories suggest a different definition of power. Hannah Arendt, whose definition frequently appears in Feminist studies, defines power as human ability to act in concert with others who share similar concerns (Tickner 1992, 65). It has been argued that given that women have had less contact with coercion (the way that power is usually used in international relations), they usually use persuasion as a way of gaining power through coalition building. Ann Tickner argues that although power is frequently used in a coercive mode, thinking about power in cooperative terms is helpful for devising solutions necessary for solving some security threats (Tickner 1992, 65).

\subsection{Security}

I want to focus on Feminist approach to security as a good example illustrating Feminist challenge to mainstream IR. I have chosen the concept of security because it is a central concept for the discipline. Moreover, Feminist writers wrote extensively on the concept of security. Feminist definitions of security and explanations of insecurity show their divergence from conventional international theory in a clear way.

Feminists start their discussion on security with focusing on Realist definition of security. As Feminists argue that Realist scholars define security in political and military terms, as the protection of the boundaries and integrity of state against the dangers of a harsh international environment (Tickner 2001, 38). In an attempt to provide a more developed explanation, Neo-Realists emphasize the anarchical structure of the system rather than domestic factors as the main reason for insecurity of states'. States are viewed as unitary actors whose internal characteristics, except for their relative capabilities, do not matter (Tickner 2001, 39).

Feminist IR scholars challenged the role of states as efficient security suppliers. It has been argued that state violence is a significant problem in some states. Moreover, it has been argued that a lot of states sustain huge military budgets at the expense of social spending during peacetime. Feminists argue that this too can be a form of violence (Tickner 2001, 62). Thus, feminist writers emphasized that threats do not only come from the other states but also from the state itself and that internal conflicts may also contribute to the insecure environment. Moreover, as Hoffman explains, the biggest menace to people's security might be the state agents, military personnel or dominant men who are expected to be the protectors of the weak and who allege to be guardians of order (Hoffman 2001, 95).

Many feminist scholars have adopted a multidimensional and multilevel approach to security in an attempt to broaden the definition of security (Tickner et. al, 2004, 48). In Feminist understanding, political, economic and ecological dimensions are as important as military dimensions. Thus, feminism, in opposition to Realism, defines security as elimination of all kinds of violence as well as unjust social relations. Feminists' commitment to the emancipatory goal of ending women's subordination is consistent with this broad definition of security that focuses on individuals.

According to Feminists, a more global vision of security is needed rather than a state-centric one. They advocate that the behaviour of the individuals and the domestic politics of states cannot be separated from the states' behaviour in the international system. Furthermore, Feminists assert that a very limited number of women have participated in security decision-making and implementation. As a result, the security decisions of states reflect masculine orientations. Instead of this a people-centred security is needed. This notion of security goes beyond state and national boundaries (Hoffman 2001, 102). Feminist writers such as Roberts argued that due to genderblindness Realists rendered domestic violence against women invisible and as a result they made false assumptions about the 'peacefulness' within societies, which is often contrasted with the violence between nations. This gender blindness also fails to realize the fact that it is usually men who exercise power over other man and over other woman (Roberts 1983).

To sum up, feminist IR states that traditional understanding of security in IR has remained short of considering and investigating the situation of women. To exemplify, they have been unsuccessful in taking account of the specific ways in which women and children are influenced by war, military occupation, militarization, forced migration, human trafficking, sexual and other forms of slavery and forced prostitution in wars (Youngs 2004). However, it should not be forgotten that issues of global security are interrelated with and to some extent constituted by local issues, which absolutely involve women and their situations (Tickner 1992). As a result, comprehensive action in the realm of security requires action that involves both women and men at all levels of society and this action is only possible if strict gender hierarchies are unsettled. In addition, the full and effective promotion of women's rights can be best 
realized in conditions of international peace and security where relations among states rest on the respect for the legitimate rights of all nations and people to self determination, independence, sovereignty, territorial integrity and the right to live in peace (Reardon 1993).

\subsection{Rationality}

Rationality is also a critical concept in Realism. It is the instrumental reason that shapes the world-view of states. Rationality shapes states' perception of the international sphere as an anarchical- without formal structure and order- and a hostile space where states are insecure. As a result of rationality, states pursue their exclusive national interest. To the extend that states share common interests, the theory of rational interest tells us that these cannot be realised without a legal order with a coercive power (True 1996, 255).

Feminists argue that this realist form of rationality is gendered. It doesn't leave room for relationships other than the selfhelp ones. This happens because rationality is a detached masculine way of seeing the world. This model takes the world as inherently conflictual because it is away from realising the reality of social relations embedded in interdependencies. Feminists further argue that rational knowledge is made possible by the gendered division of labour that makes women responsible for human relationships and the reproduction of everyday life, making cooperation for the a daily reality, and relieving man of these necessities (True 1996, 256).

\subsection{State}

States and sovereignty are at the center of the practice and the study of international relations. As Peterson argues states remain to be monopolize our understanding of how we organize ourselves politically, how political identity is constituted, and where the boundaries of political community are drawn (Peterson 1994, 32). Feminist writers argue that due to its monopoly on the legitimate use of force, the state is both the most threatening actor in the world (Runyan 1991, 85).

Feminists argue that mainstream IR has long taken state for granted; it did not examined how it is a historically constructed institution. Yet, the feminists argue, women's and men's experiences of states and citizenship vary enormously (Petmann 1996, 3). States are changing, as process of globalization and fragmentation undermine states from above and below. Feminists assert that states, sovereignty, and so IR require a new thinking, in way that takes both global dynamics and gender relations seriously (Peterson 1995, 1).

Feminist analyses argue that state is in almost all cases male dominated. Moreover, it is a masculinity construct. For feminist, it is not possible to explain state power without explaining women's exclusion from it (Pettman 1996, 5). As I will try to show in the following paragraphs, feminist focused on the origin and development of states to track women's exclusion from public power.

Feminists argue that during the early state formation, state displaced autonomous kin communities and built a separate domestic or private sphere that came be related with women and the feminine. The Athenian polis marks the emergence of the free male citizen and the construction of public space as male. Politics involved performance and presence in the public space. In the private space of the home, women and slaves were charged with sati sfying the physical and emotional needs of men. In this way, men became able to go to public space and perform his tasks as citizens (Pettman 1996, 5). Man served as soldiers and this bolstered their claim on the exclusive right of citizenship. Women had no role in conflict and therefore they had no role in the international relations between Greek city-states. The distinction between private morality and public action was transmitted to international relations. As a result, the gender bias in the Athenian city-states was transmitted to international relations (Grant 1991, 34-35).

Feminists argue that in the process of the consolidation of state power, men gain status, authority and resources as patriarchal heads of the households and as citizens participating in the newly prestigious private sphere. While men were improving their status, women lost authority and status as their biological and social reproduction capacities are placed in the private sphere (Runyan and Peterson 1991, 90). 


\section{Responses To The Feminist Challenges To The Mainstream IR}

As I tried to show so far, feminists argue that mainstream IR is oriented towards problem solving. They assert that whereas Mainstream IR is positivist and asocial, they are critical, social and post-positivist. In this section, I will be examining how these challenges were responded.

Ann Tickner argued that whereas the Feminists are inclined to critical theory, mainstream IR is oriented towards problem solving theory. As a result, Tickner argued that Realism takes the world as it finds it and accepts the current order as its framework. Moreover, Tickner argued that whereas Feminists reject prefer humanist and philosophical traditions taking spatial and temporal attributes into account, Realists rely on positivist epistemologies taking the natural sciences as the models to follow. Lastly, Tickner argues that whereas Feminism is associated with the social construction of reality whereas Realists opt for an atomistic, asocial conception of behavior determined by the laws of nature (Tickner 1997).

Against the criticisms of Ann Tickner, Robert Keohane argued that only a limited number of major IR theorists are oriented towards problem-solving, positivist and asocial (Keohane 1998, 194). Keohane focuses on Morgenthau since most of the criticisms of Tickner concentrates on him. Keohane argues that since Morgenthau was a refuge from Nazism, he was not satisfied with the prevailing world order of the late 1930's and 1940's as a framework of analysis. Moreover, Morgenthau had an intensely normative purpose: to prevent the reoccurrence of war generated by ideologies such as fascism and communism. Kenneth $\mathrm{N}$. Waltz, the leader in Neo-Realist Theory, underlined the importance of socialization in the world politics and as a result it not appropriate to regard him an advocate of asocial theories (Keohane 1998, 194).

Against the last criticism of Tickner, Keohane argued that "no serious student of international relations expect to discover meaningful universal laws that operate deterministically, since they recognize that no generalization is meaningful without specification of its scope conditions. One can recognize that knowledge is socially constructed without giving up the efforts to widen intersubjective agreement on important issues" (Keohane 1998, 194).

\section{Conclusion}

Feminist challenge to mainstream IR cannot be deemed successful in reconstructing IR although its main aim is to do so. The Realist did not attempt to reconsider their claims in the light of feminist criticisms but they posed countercriticisms to feminists in an attempt to defend themselves. Keohane's effort deserves respect as his responses were really to the point. But his attitude has been quite exceptional.

This is hardly surprising if one is familiar with the settled schools and dynamics of IR. First of all, the concerns of Feminism and Realism are quite different from each other. Whereas the feminists aim to end gender inequalities, Realism since its foundation is preoccupied with pursuing national interest. Second, the Feminist challenge to the mainstream IR goes to very heart of the mainstream. Feminists pose quite formidable challenges to the mainstream. Feminists content that women have not been studied in IR because the conceptual framework of the entire fi eld is gendered. In addition, Feminists challenge the objectivity of mainstream by pointing the sources of gender bias in the mainstream. Moreover, Feminists argue that mainstream must move beyond a mere focus on the state level. Mainstream must also examine what is happening in the societies to have a more comprehensive and an appropriate understanding. Feminists also try to teach the mainstream to be tolerant of difference. As a result, FeministMainstream engagements proved to be troubled and unproductive. Feminist-Realist encounters did not bring about changes in the theorization of the mainstream. Mainstream opted for ignoring the challenges that Feminist IR scholars posed. But although feminism is unsuccessful at reconstructing IR, it still can be considered as an attempt to open up spaces for critical examination. This is due to the reason that although gender as a variable remains short of accounting for the complex and multidimensional global politics on its own, it still enriches our understanding as it provides new perspectives previously excluded by the Mainstream IR.

\section{References}

[1] Elshtain, J. B. (1981). Public Man, Private Woman: Women in Social and Political Thought. Oxford: Martin Roberson Press.

[2] Enloe, C. H. (2010). Nimo's war, Emma's war: Making feminist sense of the Iraq war. Univ of California Press. 
[3] Enloe, C. (2014). Bananas, beaches and bases: Making feminist sense of international politics. Univ of California Press.

[4] Grant, R. (1991). In Grant R. and Newland K. The sources of gender bias in international relations theory. Gender and international relations, 8-26.

[5] Grant R. and Newland K. (1991). Gender and International Relations. Indianapolis: Indiana University Press.

[6] Halliday, F. (1994). Hidden from international relations: women and the international arena. In Rethinking International Relations (pp. 147-169). Macmillan Education UK.

[7] Hoffman, J. (2001). Gender and sovereignty: feminism, the state and international relations. Palgrave.

[8] Keohane, R. O. (1998). Beyond dichotomy: Conversations between international relations and feminist theory. International Studies Quarterly, 42(1), 193-197.

[9] Peterson, V. S. (1994). Gendered States: Feminist Visions of International Relations Theory.

[10] Peterson, V. S. (1995). Reframing the politics of identity: Democracy, globalization and gender. Political Expressions, 1(1), 1-16.

[11] Peterson, V. S. (2004). Feminist Theories Within, Invisible To, and Beyond IR. Th e Brown Journal of World Affairs, 10(2), 35-46.

[12] Pettman, J. J. (1996). Worlding women. A Feminist International Politics. St Leonards: Allen\&Unwin.

[13] Reardon, B. (1996). Sexism and the war system. Syracuse University Press.

[14] Roberts, B. (1983). No safe place: the war against women. Our Generation, 15(4), 7-26.

[15] Runyan, A. S., \& Peterson, V. S. (1991). The radical future of realism: feminist subversions of IR theory. Alternatives: Global, Local, Political, 16(1), 67-106.

[16] Shepherd, L. J. (2010). Sex or gender? Bodies in world politics and why gender matters. Gender Matters in Global Politics: A Feminist Introduction to International Relations. London: Routledge, 3-16.

[17] Steans, J. (2003). Engaging from the margins: feminist encounters with the 'mainstream'of International Relations. The British Journal of Politics and International Relations, 5(3), 428-454.

[18] Tickner, J. A. (1988). Hans Morgenthau's principles of political realism: A feminist reformulation. Millennium: Journal of International Studies, 17(3), 429-40.

[19] Tickner, J. A. (1991). On the fringes of the world economy: A feminist perspective. In The New International Political Economy (pp. 191-206). Palgrave Macmillan UK.

[20] Tickner, J. A. (1992). Gender in international relations: Feminist perspectives on achieving global security. New York: Columbia University Press.

[21] Tickner, J. (1997). You just don't understand: troubled engagements between feminists and IR theorists. International Studies Quarterly, 41(4), 611-632.

[22] Tickner, J. A. (2001) Gendering World Politics: Issues and Approaches in the Post-Cold War Era. New York: Columbia University Press.

[23] Tickner, J. A., Buchwalter, S., Finklestein, J., \& Sherman, L. (2004). The Growth and Future of Feminist Theories in International Relations. The Brown Journal of World Affairs, 10(2), 47-56.

[24] Tickner, J. A. \& Sjoberg L. (2013). Feminism (pp. 205-223). In Dunne, T., Kurki, M., \& Smith, S. (2013). International relations theories. Oxford University Press.

[25] True, Jacque (1996). Feminism (231-276). In Burchill S., Devetak R., Linklater A., Matthew Peterson, Reus-Smit C. and True J. (eds.). Theories of International Relations. New York: Palgrave

[26] Wibben, Annick TR. "Feminist international relations: Old debates and new directions." The Brown journal of world affairs 10.2 (2004): 97-114.

[27] Youngs, G. (2004). Feminist International Relations: a contradiction in terms? Or: why women and gender are essential to understanding the world 'we'live in. International Affairs, 80(1), 75-87. 